UDK 27-789Ureman, I.

\title{
Ivan Ureman - posrednik između kineske i europske znanstvene tradicije
}

\author{
Povodom 400. obljetnice njegove smrti u jubilarnoj Ignacijevoj \\ godini (2021.-2022.)
}

\section{Marijana Boric**}

\begin{abstract}
Sažetak
U radu je prikazano djelovanje Ivana Uremana (1583.-1621.), hrvatskoga isusovca, misionara, matematičara i astronoma. Uremanov rad razmatran je iz dva aspekta. Prvi je sagledavanje Uremanova rada u sklopu razvoja znanosti njegova doba. Svojim radom na području matematike, kao i u astronomiji, Ureman se pridružuje onim učenjacima s početka novovjekovlja koji su matematičkim pristupom tražili nova znanja i uvide u spoznaju zbilje. U radu su Uremanovi znanstveni interesi $i$ doprinosi prikazani u šrem kontekstu znanstvenih prilika na prijelazu iz 16. u 17. stoljeće. Kao misionar djelovao je u razdoblju glasovitih isusovačkih misija na Dalekom istoku, pa je njegov rad također razmatran iz vidika prijenosa znanja i djelovanja prvih posrednika između kineske i europske kulturno-znanstvene tradicije.

Ključne riječi: Ivan Ureman; isusovci misionari; astronomija; geometrija; euklidska aksiomatika; magnetska deklinacija; zemljopisne koordinate; kineska znanstvena tradicija
\end{abstract}

\section{Uvod}

Četristota obljetnica smrti Ivana Uremana (Vremana), u jubilarnoj Ignacijevoj godini, ${ }^{1}$ prigoda je da sagledamo i detaljnije razmotrimo njegov znanstveni rad, kao i posredovanje između kineske i europske znanstvene tradicije. Taj istaknuti isusovac, misionar, matematičar i astronom neosporno se ubraja među znamenite hrvatske humaniste koji su tijekom 16. i 17. stoljeća djelovali izvan domovine i uživali neprijeporan ugled $\mathrm{u}$ intelektualnim krugovima onodobne

* Dr. sc. Marijana Borić, Hrvatska akademija znanosti i umjetnosti, Zavod za povijest i filozofiju znanosti. Adresa: Ante Kovačića 5, 10000 Zagreb, Hrvatska. ORCID iD: https://orcid.org/0000_ 0002-0044-0888. E-adresa:mbuljan@hazu.hr

1 Generalni poglavar Družbe Isusove Arturo Marcelino Sosa Abascal najavio je jubilarnu Ignacijevu godinu pismom od 27. rujna 2019. godine. Početak jubileja bio je 20. svibnja 2021., na 500. obljetnicu obraćenja sv. Ignacija. Središnji je datum jubilarne godine 12. ožujka 2022., kad je 400. obljetnica Ignacijeve kanonizacije, a njezin je zaključak na liturgijski spomendan sv. Ignacija 31. srpnja 2022. godine. 
Europe. Privučen isusovačkom misijom širenja evangelizacije te bogatom i u to vrijeme slabo poznatom tradicijom Dalekoga istoka, Ureman se je priključio isusovačkim misionarima koji su na prijelazu iz 16. u 17. stoljeće djelovali kao prvi posrednici dviju velikih kultura, europske i kineske, te stvarali veze između religija kršćanstva i budizma, odnosno konfucionizma, i kulturno-znanstvenih tradicija Istoka i Zapada. Njegov je život i rad bio predmetom istraživanja stručnjaka iz različitih područja. ${ }^{2}$ Usprkos tomu, postoje mnoge nedoumice i otvorena pitanja. Propitivanjem slabije poznatih segmenata, njihovim sagledavanjem iz različitih aspekata te stavljanjem u širi povijesni i znanstveni kontekst upotpunjuje se slika o životu Ivana Uremana, njegovu znanstvenom radu i ulozi u prijenosu znanja između znanstvenih sustava Dalekoga istoka i Zapada.

\section{1. Školovanje u splitskom humanističkom krugu}

Ureman je rođen 6. lipnja 1583. godine u Splitu (Korade, 1985, 102). Njegov se životni put u osnovnim crtama može rekonstruirati na temelju službi, a biografski su podatci vrlo oskudni. Ponešto iz njegove mladosti moguće je rekonstruirati uzimajući u obzir povijesne i kulturne prilike u Splitu tijekom 16. stoljeća. ${ }^{3}$ Renesansa je u čitavoj Dalmaciji zaživjela već krajem 14. stoljeća, ponajprije zbog blizine talijanskih kulturnih središta. ${ }^{4}$ Split iz doba Uremanove mladosti pokazuje

2 Zapisi i radovi o Uremanu objavljivani su od 17. stoljeća do danas. Prvo je Uremanov nekrolog načinio tamošnji misionar Francisco Furtado, na temelju neposrednoga svjedočanstva, a objavljen je u izvješću kineskih misija za godine 1619.-1621., koje je 1622. potpisao prokurator Kine Nicole Trigault (Relatione, 1624, 145-150). To je izvješće doživjelo pet izdanja (prvo na talijanskom 1624. u Rimu, na francuskom u Parizu 1625. i 1627., na latinskom u Münchenu 1627., i još dva puta na talijanskom u Rimu i Milanu 1627.) (Sommervogel, V, 258, 360, VIII, 242-243). Uremanovu biografiju donosi i Daniello Bartoli u monumentalnom djelu Dell' historia della Compania di Gesu: La Cina: Terza parte dell' Asia, Romae 1663. (Bartoli, Opere, XVII, 1825, 288), a spominje ga i kineski misionar Philipe Couplet u svojem katalogu isusovačkih misionara (Couplet, 1686, 18). Spominju ga u 18. stoljeću povjesničari Giuseppe Patrignani u svojoj povijesti isusovačkoga reda (Patrignani, 1730, 128-129) i Giulio Cesare Cordara (Cordara, 1750, 275-276). U 19. stoljeću objavljen je segment Uremanova pisma Grienbergeru u korespondenciji talijanskoga astronoma Maginija (Favaro, 1866, 323-327). U 20. stoljeću više je stranih i domaćih autora pisalo o Uremanu, među kojima David Czvittinger (1911, 395), Carlos Sommervogel (V, 258, 360, VIII, 242-243), Louis Pfister (1932, 149-150), Žarko Dadić (1982, 197-201; 1985; 2017, 177-185), Mijo Korade (1985; 1991, 11-14 i 105-107; 2003, 264-265) i Juan Ruiz de Medina (1993).

3 Složene i iznimno nepovoljne političke prilike u kojima su se našle razjedinjene hrvatske zemlje tijekom cijeloga 16. stoljeća, kada su Osmanlije osvojile veći dio hrvatskih zemalja (Slavoniju, Liku, Krbavu i južnu Hrvatsku), osobito nakon Mohačke bitke 1526. i pada Ugarskoga Kraljevstva, zbog čega je hrvatski Sabor 1561. preostale slobodne dijelove teritorija nazvao "ostatcima ostataka nekoć slavnoga Hrvatskog Kraljevstva”, odražavale su se i na život u Splitu, čije je neposredno zaleđe tijekom 16. stoljeća bilo izloženo konstantnim osmanlijskim prodorima, teritorijalnim pretenzijama Mletačke Republike i Habzburgovaca. Usprkos teškim političkim, gospodarskim i društvenim prilikama to ipak nije priječilo da na područje grada Splita, kao i drugih gradova hrvatskoga priobalja već vrlo rano dopiru utjecaji humanizma iz susjedne Italije.

4 Prihvaćanjem novoga svjetonazora, okrenutoga univerzalnosti, kozmopolitizmu, antropocentričnosti i obnovi interesa za antičko nasljeđe, od 15. stoljeća svaki je veći grad uz hrvatsku obalu, pa tako i Split, njegovao vlastiti humanistički krug unutar kojega su djelovali istaknuti pojedinci. Humanizam je utjecao na kulturni život gradova u kojima su djelovali kulturni krugovi i škole koje su organizirale gradske vlasti ili crkveni redovi, što je bilo od važnosti za život zajednice. 
kontinuitet stvaralaštva od preko stotinjak godina, tijekom kojih su u splitskom humanističkom krugu djelovala imena koja danas smatramo velikanima hrvatske kulture. ${ }^{5}$ Može se pretpostaviti da je Ureman do sedamnaeste godine pohađao neku od ondašnjih škola jer je Split, kao i drugi veći gradovi hrvatskoga priobalja, koji su u to vrijeme imali razvijenu kulturnu fizionomiju, imao i društvenu brigu o javnim službama potrebnima za život grada, pa tako i za prenošenje znanja. Imao je organizirane škole u kojima su se pripremali mlađi naraštaji za obavljanje različitih poslova u službi grada. Ureman je prije odlaska iz rodnoga grada stekao početno obrazovanje, te se je vjerojatno u toj školi istaknuo nadarenošću. To je vodilo tomu da bude poslan u Rim 1600. i primljen u novicijat Družbe Isusove te usmjeren nastavku školovanja.

\section{Studij u Rimu}

Godine 1602. započeo je studije na Rimskom kolegiju (Collegium Romanum) (Korade, 1985, 102-103). U sklopu studija filozofije izučavao je prirodnu filozofiju, matematiku i astronomiju. Na drugoj godini filozofije matematiku mu je predavao Oddo Van Maelcote (Malcotius). ${ }^{6}$ Imao je utjecaj na razvoj Uremanovih znanstvenih interesa i na njegove kontakte s drugim učenjacima u krugu Rimskoga kolegija, ${ }^{7}$ među kojima su se isticali Christophor Clavius ${ }^{8}$ i Christoph Grienberger. ${ }^{9}$

5 U Splitu isticale su se tijekom 15. i 16. stoljeća ugledne osobe iz hrvatske povijesti, koje su rođene, školovale se ili djelovale u Splitu, kao dominikanac Benjamin (prvi posrednik između zapadnoeuropske i ruske, bizantsko-pravoslavne tradicije), Marko Marulić, Petar Hektorović, Aleksandar Komulović i drugi. Markantun de Dominis velik je dio svojega opusa načinio u Splitu, a obnašao je dužnost splitskoga nadbiskupa i primasa Hrvatske i Dalmacije.

6 Oddo Van Maelcote (Bruxelles, 1572. - Rim, 1615.) objavio je djelo o ekvinocijalnom astrolabu, koji je sam konstruirao i izradio. Sadržavao je dvije spojene hemisfere i bio koristan za misionarske pothvate širom svijeta, jer se je mogao koristiti i na sjevernim i na južnim geografskim širinama. To mu je priskrbilo ugled poziv da na Rimskom kolegiju predaje matematiku i radi na zvjezdarnici. Bio je 1610. dio četveročlane komisije (Clavius, Grienberger, Lembo) koju je angažirao kardinal Bellarmino da dade svoje mišljenje o Galileovim otkrićima. U vezi s tim od 1612. do 1614. vodio je prepisku s Keplerom.

7 Zanimljiv je podatak kako je baš u razdoblju Uremanova školovanja u Rimu, tijekom 1602. i 1603. godine, u tom istom kulturnom krugu djelovao i Marin Getaldić (Dubrovnik, 1568. — Dubrovnik, 1626.), najistaknutiji hrvatski matematičar i fizičar te epohe, kojega su Clavius i Grienberger osobito cijenili, a bio je uvažavan i u drugim elitnim znanstvenim krugovima onodobne Europe u kojima se je razvijala novovjekovna matematika i prirodna znanost, poput Galileova kulturnoga kruga u Padovi i Vietèova krugu u Parizu. Getaldić je u tom razdoblju boravio u Rimu kako bi objavio svoje prvijence, fizikalno djelo Promotus Archimedes (Rim, 1603.) i matematičku raspravu Nonnullae propositiones de parabola (Rim, 1603.), o čemu se je konzultirao s Claviusom i Grienbergerom. Premda su se mladi Ureman i tada već ugledni Getaldić u to vrijeme u Rimu kretali u istim krugovima i dijelili interes prema istim područjima, nema svjedočanstva o njihovu međusobnom kontaktu.

8 Christophor Clavius (Bamberg, 1538. - Rim, 1612.) njemački je matematičar i astronom. Pola stoljeća predavao je matematiku i astronomiju na Rimskom kolegiju. Napisao je više djela i smatran je jednim od najuglednijih astronoma i matematičara svoje epohe, nazivan Euklidom 16. stoljeća. Istaknuo se je sudjelovanjem u reformi gregorijanskoga kalendara, o čemu je napisao i raspravu.

9 Christoph Grienberger (Tirol, 1561. — Rim, 1636.), austrijski matematičar i astronom, Claviusov učenik i suradnik. Predavao je matematiku u Beču, a zatim tridesetak godina na Rimskom ko- 


\subsection{Uključivanje u znanstveni rad}

Studij filozofije Ureman je dovršio 1607. godine te se je uključio u znanstveni rad. Počeo je obavljati astronomska istraživanja, posebno u vezi s proučavanjem pomrčine Mjeseca, što ga je zaokupljalo sve do konca života. Studirao je teologiju u razdoblju od 1607. do 1609. godine i dopisivao se je s uglednim astronomom Giovannijem Antoniom Maginijem (lat. Magnus). ${ }^{10}$ Izmjenjivali su praktična i teorijska saznanja i rezultate astronomskih opažanja. Ureman se je zanimao za novosti u astronomskoj zajednici, osobito za rad Tycha Brahea, što doznajemo iz pisma koje je uputio Maginiju (Favaro, 1866, 323-327). Ureman je jedno od astronomskih opažanja poduzeo u noći između 19. i 20. siječnja 1609. u društvu Claviusa, Grienbergera i Maelcotea. Načinio je i detaljan opis pomrčine Mjeseca, o čemu svjedoči pismo koje je 31. siječnja 1609. uputio Maginiju i u kojem je priložio opis motrenja (Favaro, 1866, 323-327). ${ }^{11}$ Opisuje otežano motrenje zbog gustih oblaka, loših atmosferskih prilika i malo astronomskih instrumenata. Najvjerojatnije se je služio samo s kvadrantom za određivanje visine zvijezda, bez pomoći teleskopa, koji je tijekom te 1609. godine konstruirao Galilei, što je ubrzo dovelo do velikih astronomskih otkrića, koja su odjeknula u rimskim krugovima nedugo nakon Uremanova odlaska iz Rima. ${ }^{12}$ Kako prvih godina od izuma teleskop nije bio lako dostupan, Ureman je i svoja kasnija opažanja također izvodio bez uporabe teleskopa. Stoga je osmišljavao posebne opažačke i metodičke postupke, pomoću kojih je procjenjivao kvantitativna obilježja pojava. Nastojao je odrediti vrijeme ulaska i izlaska Mjeseca iz sjene, što su mu otežavali oblaci prikrivajući Mjesec u trenutku ulaska u sjenu. Prema njegovu zapisu nebo se je kasnije razvedrilo i omogućilo uspješno motrenje kraja pomrčine. Opisana opažanja daju uvid u Uremanov pristup i metodi. Cilj motrenja bio je odrediti vrijeme izlaska Mjeseca iz sjene, kako bi se ti rezultati mogli usporediti s rezultatima dobivenim iz astronomske teorije. Zbog nedostatka preciznijih instrumenata Ureman je bio svjestan mogućih pogrešaka, pa se je odlučio na određivanje maloga vremenskoga intervala, ali ipak dovoljno velikoga kako bi sadržavao pra-

legiju. Pisao je matematičke komentare na djela iz antičke tradicije, a istaknuo se je i u povijesti kartografije. Grienbergerova predavanja iz astronomije na Rimskom kolegiju bila su također i priprema za njegovu subraću isusovce koji su se upućivali u misionarski rad na Dalekom istoku. Njemu u čast jedan je krater na Mjesecu nazvan Gruemberger.

10 Giovanni Antonio Magini (Padova, 1555. - Bologna, 1617.), talijanski astronom, kartograf, matematičar i astrolog. Smatran je jednim od najvećih kartografa svojega vremena. Dopisivao se je s Keplerom, Bracheom, Claviusom i dr. Autor je nekoliko astronomskih djela. Priredio je kritičko izdanje Ptolomejeve Geografije tiskane prvi put u Veneciji 1596. godine. Obrađivao je veliku zbirku zemljopisnih karata, posthumno objavljenu u Bologni 1620. godine. Njegovo ime nosi krater na Mjesecu (Maginus).

11 Budući je Uremana problem određivanja pomrčine Mjeseca zaokupljao čitava njegova života, pojedini istraživači pretpostavljaju kako je s Maginijem izmijenio više pisama (Dadić, 2017, 178).

12 Galilei je 1609. otkrio Saturnov prsten, Venerine mijene, Jupiterove mjesece i Sunčeve pjege. Godine 1610. inkvizicija i visoki crkveni službenici obratili su se Grienbergeru, Claviusu, Lembu i Maelcoteu za mišljenje o Galileovim otkrićima. Grienberger se je slagao s Galileovom teorijom, ali je Claudio Acquaviva, general isusovačkoga reda, zatražio da povjerenstvo podrži geocentrični, aristotelovski pogled na ustroj svemira. 
vi trenutak u kojem se izlazak Mjeseca iz sjene mora dogoditi. Odnosno Ureman se je zadovoljavao određivanjem vremenskoga intervala koji bi sadržavao rezultat dobiven računom iz teorije. Za taj postupak umjesto jednoga motrenja, koje bi se moralo načiniti točno u trenutku izlaska Mjeseca iz sjene, koristi dva uzastopna motrenja koja daju granice traženoga intervala unutar kojega se je dogodio izlazak Mjeseca iz sjene. ${ }^{13}$ Kako bi točno odredio vrijeme dvaju motrenja početka i kraja traženoga intervala vremena, budući da nije raspolagao preciznim satovima, Ureman je promatrao visine zvijezde Srce Lava, ${ }^{14}$ a potom iz njih određivao vrijeme. Dobivene rezultate opažanja usporedio je s računski dobivenim vremenom kraja pomrčine. Taj je rezultat dobiven iz astronomske teorije bio unutar vremenskoga intervala koji je Ureman dobio opažanjem, što je potvrdilo ispravnost njegova pristupa i metode. Pismo svjedoči kako je Ureman već kao mlad bio vrstan astronom i motritelj. U svojem radu koristio se je, uz opažanjem, i matematičkim metodama kako bi rezultate mjerenja sistematizirao i došao do novih teorijskih uvida, što je rani primjer novovjekovnoga pristupa istraživanju prirodnih znanosti.

\subsection{Uremanov matematički rukopis Geometriae speculatiuae compendium}

Ureman se je znanstvenim radom bavio i tijekom višegodišnjega putovanja preko Španjolske, Portugala i Indije do misija na Dalekom istoku. Nakon što je poslan u azijske misije 1609., otišao je iz Rima i nekoliko je godina do 1615 . čekao polazak brodovlja iz Portugala i Španjolske. ${ }^{15}$ Za to je vrijeme bio profesorom matematike u Oropesi (Korade, 2003, 263). Iz toga je razdoblja sačuvan njegov matematički rukopis Geometriae speculatiuae compendium ("Priručnik spekulativne geometrije") ${ }^{16}$, koji je vjerojatno načinio za potrebe poučavanja. To je zasada jedino poznato Uremanovo matematičko djelo, iz kojega je moguće rekonstruirati i valorizirati njegove matematičke interese, pristupe i stavove koje je zastupao, postavljajući ih u širi kontekst povijesnoga razvoja matematike. ${ }^{17}$ O Uremanu je pisalo više povjesničara navodeći ga kao vrsnoga matematičara. Povjesničar David Czvittinger (1675.?-1743.) u svojem djelu Specimen Hungariae literatae, virorum eruditione clarorum natione Hungarorum, Dalmatarum, Croatarum, Slavorum iznosi mišljenje kako je bio vješt u matematici (Czvittinger, 1911, 395), a francuski isusovac, povjesničar i sinolog Louis (Aloys) Pfister u bibliografiji starijih kineskih misionara navodi kako je Ureman bio eminentni genij i odličan matematičar (Pfister, 1932, 149-152). To upućuje na zaključak da se pored nastave matematike bavio i matematičkim istraživanjima koja su dala zapaženih

13 Trenutak izlaska Mjeseca iz sjene ne smatra aritmetičkom ili nekom drugom sredinom dobivenoga intervala, nego se zadovoljava činjenicom da je sadržan u procijenjenom intervalu.

14 Riječ je o najsjajnijoj zvijezdi u zviježđu Lava latinskoga imena Regulus (Alfa Leonis).

15 Mijo Korade $(1985,103)$ ispravio je krivi podatak ponavljan u literaturi da je Uremana 1615 . u Kinu poveo sa sobom prokurator Kine Nicola Trigault. To je netočno jer je Trigault krenuo iz Macaa 1613., a vratio se u Kinu 1618. godine.

16 Ureman, Ioannes, Geometriae speculatiuae compendium. Rkp. Katalog K III a y, 32r-37v.

17 Prvi je o tom Uremanovu rukopisu pisao Žarko Dadić (1985). 
rezultata. Međutim, osim spomenutoga rukopisa do sada nisu poznati drugi Uremanovi matematički tekstovi koji bi to potvrdili. Ureman je izučavao Euklidove Elemente, djelo nastalo u 4. stoljeću pr. Kr. s ciljem da zacrta temelje za izgradnju cijele geometrije. Presudno je utjecalo na razvoj matematike naredna dva tisućljeća. ${ }^{18}$ Bilo je predmet izučavanja matematičara renesanse, jer su u antici tražili uzore za izgradnju nove matematike. Renesansna nastojanja da se matematičkim pristupom i na temeljima antičke tradicije ostvari nova spoznaja zbilje dosežu svoj vrhunac upravo u Uremanovo doba. Svojim izučavanjem Elemenata i Ureman se je priključio združenim snagama učenjaka koje, nakon akumulacije antičkih znanja, nastoje prerasti antičku tradiciju, osuvremeniti ju te formalno prilagoditi matematici svojega vremena. Uremanov rukopis Geometriae speculatiuae compendium preradba je prve, najvažnije od trinaest knjiga Euklidovih Elementa. ${ }^{19}$ Usporedbom Uremanova rukopisa i Euklidova djela vidljiva su odstupanja u sadržaju, strukturi i formalnom oblikovanju matematičkoga gradiva. Ureman, u skladu s tadašnjim razvojem matematike, nastoji dati matematički razrađeniji i formalniji oblik od izvornoga antičkoga. Premda je Ureman u svoj rukopis na više mjesta unosio vlastite preinake, njegov je rad u znatnoj mjeri pod utjecajem Claviusa i Grienbergera, koji su radili na komentarima i preradbi prvih šest knjiga Euklidovih Elementa prilagođavajući ih obilježjima kasnorenesansne matematike. ${ }^{20} \mathrm{U}$ tom su ih obliku prenosili na predavanjima i u krugu Rimskoga kolegija, gdje ih je imao prilike izučavati Ureman. Usporedba Uremanova rukopisa i Grienbergova teksta pokazuje znatne sličnosti, kao i podudarnosti u odstupanju od Euklidova teksta u dva aspekta. Prvo u pogledu raščlambe i strukturiranja definicija koje određuju matematički pojam i omogućuju da pojmovi budu shvaćeni. Euklid je dao 23 definicije, kojima je htio dati zornu predodžbu o osnovnim matematičkim pojmovima, a kod Grienbergera i Uremana ima ih po 36 (Dadić, 2017, 184). Međutim, premda Ureman i Grienberger imaju više definicija od Euklida, oni nisu među definicije uveli nove matematičke pojmove, nego su postojeće Euklidove definicije detaljnije raščlanili i strukturirali, kako bi se jednostavnije koristile u izvođenju matematičkoga dokaza. Nešto znatnije promjene u odnosu na izvorni Euklidov tekst načinjene su u pogledu aksioma i postulata (Dadić, 2017, 184). Te promjene proizlaze iz razlike u poimanju i gledištima koja su Ureman i Grienberger imali u odnosu na Euklida. ${ }^{21}$ Euklid, koji

18 Smatraju se temeljima matematike kakvu danas poznajemo. Imaju oko 1.700 izdanja, a i danas su utjecajni u matematici.

19 Malo je djela toliko komentirano i doživjelo preradbi kao to u kojem Euklid želi dati sigurne temelje za izgradnju matematičkoga sustava.

20 Clavius je načinio komentare uz prvih šest knjiga Elementa, koje je Grienberger prilagodio svojemu shvaćanju i vremenu te objavio pod naslovom Euclidis sexs primi elementorum libri cum parte undecimi: Ex majoribus Clavii commentariis in commodiorem formam contracti et P. Christophorum Grienbergorum e Societate Jesu (Graecii, 1636., str. 165-171).

21 U raznim izdanjima Elemenata raspored postulata i aksioma nije isti, kao ni njihov broj. U nekim izdanjima ima samo tri postulata, a preostali su navedeni kao aksiomi. U nekim izdanjima ima čak jedanaest aksioma. Prema današnjem shvaćanju nema razlike između aksioma i postulata (Euklid, 1999, 239). 
je bio pod utjecajem Aristotelova učenja, usvojio je podjelu temeljnih tvrdnji na aksiome i postulate te je pravio distinkciju među njima, tako da je postulatima izražavao čisto geometrijske činjenice, a aksiomima činjenice o općim veličinama, koje vrijede općenito u svim znanostima, pa tako i u matematici. ${ }^{22}$ Grienberger, pod čijim je utjecajem bio Ureman, shvaćao je aksiome i postulate drugačije od Euklida (Dadić, 1985). Smatrao je da su postulati praktične tvrdnje i postavljaju se kao same po sebi poznate, a aksiomi su spekulativne tvrdnje kojima nije potreban dokaz (Grienberger, 1636, 4). Upravo su zato neki postulati preneseni u aksiome i kod Uremana i kod Grienbergera. Prva knjiga Euklidovih Elemenata ima ukupno devet aksioma, a Grienberger ih ima dvadeset, kao i Ureman, izričajem i sadržajem gotovo potpuno istih (Dadić, 1985). Pored toga, u prvoj knjizi Euklid donosi 48 poučaka, koje istim redoslijedom prenose u svojim tekstovima Grienberger i Ureman. U dokazima tih problema Euklid se koristi prethodno navedenim aksiomima, postulatima i već dokazanim tvrdnjama, ali ih ne navodi po njihovom rednom broju, pa je njegovo izvođenje matematičkoga dokaza, premda u potpunosti korektno, ipak teško pregledno. Euklidovu formulaciju poučaka dotjerao je Clavius, a njihove dokaze neovisno jedan o drugom Grienberger i Ureman, eksplicitno se pozivajući na tvrdnje koje koriste u izvođenju dokaza. Stoga su njihove prerade Elemenata formalno sređenije, sažetije i matematički dotjeranije u odnosu na izvornoga Euklida. Ureman, premda je bio pod utjecajem Grienbergova i Claviusova rada, unosio je i vlastite preinake, ${ }^{23}$ kao i alternativne dokaze, koji potvrđuju da je bio vrstan matematičar i samostalan u istraživačkom radu, te dobar poznavatelj euklidske metode i novoga, formalnijega matematičkoga pristupa problemima. Rukopis je Ureman koristio za potrebe nastave matematike u španjolskoj Oropesi u razdoblju između 1609. i 1615. godine. Na rukopisu nije navedena godina nastanka, a danas se čuva u knjižnici sv. Lorenza u Escorijalu (Dadić, 2017, 182). Pretpostavlja se da bi to mogao biti prijepis Uremanova izvornika, koji je vjerojatno ponio sa sobom za potrebe poučavanja, kojim se je bavio u isusovačkim misijama u Goi, Macau i Kini.

\section{Uremanov znanstveni rad tijekom puta u azijske misije}

Pola godine nakon ukrcaja u Lisabonu Ureman je stigao do Indije, $\mathrm{u}$ isusovačku misiju koja je djelovala u portugalskoj koloniji Goa. Tu je boravio devet mjeseci, nakon čega se je uputio u isusovačku misiju zasnovanu u portugalskoj koloniji Macao na južnim granicama Kine, u kojoj se je zbog progona kršćana u Kini zadržao nekoliko godina (Korade, 2003, 263). Tijekom toga razdoblja Ureman se

22 Drugi Euklidov aksiom glasi: »Ako se jednakim stvarima dodaju jednake stvari, i cjeline su jednake« (Euklid, 1999, 3). Postulati imaju drugačiju važnost i vrijede samo za određenu znanost. Treći Euklidov postulat: »I da se sa svakim središtem i udaljenošću opisuje krug« (Euklid, 1999, 3).

23 Primjerice, Grienberger u svojoj preradbi među postulatima preuzima samo tri Euklidova postulata i ne dodaje im nove. Međutim, Ureman tim trima postulatima dodaje četvrti koji glasi: svaka zadana konačna veličina u odnosu na drugu veličinu, različitu od prve, od nje je veća ili manja (Dadić, 2017, 184). 
je kontinuirano bavio znanstvenim radom. Istražujući, uočavao je duboku povezanost matematike sa zakonitostima prirode. Osim za matematiku, osobito se je zanimao za astronomiju, gdje su mu u teorijskom i praktičnom radu bila potrebna matematička znanja, te euklidska metodika za provođenje astronomskih dokaza. Matematika je implicitno prisutna u Uremanovu radu iz područja astronomije i kartografije. Istraživane astronomske probleme rješavao je planiranim motrenjima i primjenom matematike u analizi rezultata. Izborom problema i istraživačkim metodama Ureman je tematski i metodološki u potpunosti uklopljen u aktualne probleme i metodologiju ranoga novovjekovlja u zapadnoj Europi. Među područjima rada koja su ga zanimala istraživao je i magnetsku deklinaciju ${ }^{24}$ tijekom puta u Kinu, upravo u doba kada su ta motrenja, nakon otkrića Wiliama Gilberta da Zemlja djeluje kao veliki magnet, bila među najaktualnijima. ${ }^{25}$ Traženo je objašnjenje kojim bi bila rastumačena priroda pojava magnetske deklinacije i inklinacije. ${ }^{26}$ Tijekom putovanja Ureman je provodio istraživanja magnetske deklinacije, što je bilo predmet njegove prepiske s Grienbergerom. ${ }^{27}$ Ureman u pismu spominje spravu za električne pokuse nazvanu versorij, ${ }^{28}$ koju je konstruirao Gilbert. Pismo svjedoči kako je Ureman pratio otkrića i poznavao Gilbertov rad, smatran relevantnim polazištem za daljnja istraživanja (Dadić, 2017, 181). U vezi s magnetskim deklinacijama bio je i Uremanov rad na određivanju zemljopisnih koordinata. Na temelju poduzetih opažanja, određivao je razlike između europskoga i azijskoga vremena te položaje mjesta od Goe do Macaa. Dobivene rezultate slao je Grienbergeru, a tridesetak godina kasnije Uremanove je rezultate koristio i zajedno s drugim prikupljenim podatcima objavio jedan od najsvestranijih učenjaka toga stoljeća Athanasius Kircher (1654, 315-316) u svojem djelu o magnetizmu. ${ }^{29} \mathrm{U}$ to vrijeme još je bilo nepoznato da se na nekom mjestu magnetska deklinacija mijenja s vremenom, što je dovodilo do problema kada su

24 Kut između magnetskoga i zemljopisnoga meridijana.

25 Wiliam Gilbert (1544.-1603.), engleski fizičar, filozof i dvorski liječnik Elizabete I. Otkrio je elektromagnetsku indukciju i začetnik je znanosti o elektricitetu i magnetizmu. Naziv elektricitet potječe od Gilberta. U glavnom djelu De Magnete, Magneticisque Corporibus, et de Magno Magnete Tellure (1600.) iznosi zaključke o postojanju Zemljina magnetizma i tumači električne pojave objavljujući teoriju o prirodi elektriciteta. Izvodio je pokuse na modelu Zemlje zvanom terrella te je došao do zaključka o postojanju Zemljina magnetizma i tumačenja da je magnetizam uzrokom što kompas pokazuje prema sjeveru. Prije Gilberta vjerovalo se je da zvijezda Sjevernjača uzrokuje smjer pokazivanja kompasa.

26 Georg Hartman otkrio je magnetsku inklinaciju, a Robert Norman 1580. objavio je prvu kartu magnetskih deklinacija.

27 Ureman je uputio Grienbergeru pismo 20. studenoga 1616. iz Macaa, s rezultatima vrijednosti magnetske deklinacije koju je određivao na putu od Goe preko Singapura do Macaa.

28 Instrument za određivanje smjera električnoga polja.

29 Znanstveni sadržaj Uremanova pisma upućenoga Grienbergeru 20. studenoga 1616. iz Macaa objavljen je u djelu naslova Athanasii Kircheri Magnes sive de arte magnetica opus tripartitum, koje je prvo tiskano u Rimu 1641., zatim u Kölnu 1643. i ponovo u Rimu 1654. godine. Kircher je u djelo uvrstio i mnoga druga motrenja magnetskih deklinacija, osobito načinjena na Dalekom istoku, rabeći ih kao temelj svojemu izlaganju. Fragment Uremanova pisma Grienbergeru objavljen je u toj knjizi nakon podataka koje je poslao Giulio Aleni, talijanski isusovac, učenjak i misionar na Dalekom istoku. 
znanstvenici te epohe nastojali poboljšati točnost mjerenja i uskladiti rezultate s motrenjima iz starijih razdoblja. To je dovodilo do zabune i Uremana. Stoga u pismu Grienbergeru uz vrijednosti vlastitih mjerenja Ureman navodi kako su putem sve do Goe vrijednosti deklinacije sasvim različite.

\subsection{Određivanje zemljopisnih koordinata}

Povezano s istraživanjem magnetskih deklinacija bilo je i Uremanovo određivanje zemljopisnih koordinata mjesta na Dalekom istoku, koja su u to doba bila još slabo poznata. Računanje zemljopisnih koordinata uz teorijsku imalo je i veliku praktičnu vrijednost. Astronomija i kartografija neka su od područja koja su se znatno unaprijedila u tom razdoblju velikih otkrića i novih svjetova. Među najvrjednijim inovacijama smatrani su uređaji i metode za određivanje zemljopisne širine. Mjerenjem kuta Sunca i zvijezda iznad horizonta u odnosu na nebeski ekvator (astronomska deklinacija) mogao je biti određen položaj i smjer kretanja. Jednom od tih metoda određivanja zemljopisne širine ovladao je Ureman te je dao svoj prinos preciznomu određivanju zemljopisne širine za Macao. U pismu Grienbergeru od 20. studenoga 1616. navodi kako se pri određivanju zemljopisne širine služio instrumentom polukvadrantom i zemljopisnu širinu odredio pomoću visine pola koja je za Macao prema njegovu računu iznosila $22^{\circ} 15^{\prime}$ (Kircher, 1654, 315-316). U tom razdoblju znatno veći znanstveni problem predstavljalo je određivanje zemljopisne dužine. Znanstvenici 16. stoljeća pokušavali su usavršiti metode za njezino računanje jer samo poznavanje zemljopisne širine nije bilo dovoljno. Posebno se je u tom isticao Galileo. ${ }^{30}$ Pokušavajući odrediti zemljopisnu dužinu za Macao, Ureman se je odlučio koristiti rezultatima motrenjem pomrčine Mjeseca, koje je u Macau 8. listopada 1612. načinio Giulio Alieni (Dadić, 2017, 182). U pismu Ureman daje vrijeme ulaska Mjeseca u sjenu 8 sati 30 minuta i vrijeme izlaska iz nje 11 sati 45 minuta. Pored toga, za tu istu pomrčinu koristi rezultate motrenja Tiha Davida Origanija u Frankfurtu na Odri i iz toga dobiva satnu udaljenost Macao-Frankfurt, koja iznosi 6 sati 48 minuta (Kircher, 1654, 315-316).

\subsection{Dodiri Dalekoga istoka i Zapada}

Na granici Kine u Macau Ureman je proveo četiri godine, od 1617. do 1620., učio kineski jezik i predavao matematiku, a nakon ulaska u Kinu 1620. godine nastavio je s poučavanjem matematike (Dadić, 2017, 177-178, 180). Uremanovo djelovanje u Goi, Macau i Kini u potpunosti je bilo u skladu sa sveobuhvatnom ulogom isusovačkih misija toga vremena, koje su pored širenja Evanđelja imale veliku kulturnu i znanstvenu važnost (Horvat, 2002, 481-490). Kini su misionari donosili uz kršćanstvo i zapadne znanosti, za koje su kineski učenjaci pokazivali interes. Prevođena su zapadnjačka djela na kineski jezik, a posebice su se za-

30 Pokušavao je riješiti problem metode određivanja zemljopisne dužine korištenjem svojega otkrića da Jupiterovi mjeseci imaju svoje pomrčine. Premda se je dugo bavio tim problemom, njegova ideja ipak nije zaživjela. 
nimali za europsku matematiku, Euklidovu geometriju, astronomiju, prirodne znanosti, kartografiju i kalendar (Horvat, 2002, 483). Prijenos znanja tekao je u oba smjera jer su isusovci Zapadu prenosili nove znanstvene spoznaje o Kini i njezinu znanstvenom i kulturnom nasljeđu te omogućili dijalog i međusobno obogaćivanje obiju tradicija. Ureman je misionarskim radom, intelektualnom širinom, interesima i vrsnim obrazovanjem u potpunosti bio uklopljen u ciljeve i načine djelovanja isusovačkih misija na Dalekom istoku. Želeći širiti Evanđelje i kristijanizirati Kinu, isusovci su uz misionarski rad djelovali i kroz poučavanje, nastojeći preko učenih i elitnih kineskih krugova ojačali svoj utjecaj i doprijeti do širih krugova društva. Svojom izvanrednom učenošću, planskim djelovanjem i kontaktima s učenim i vladajućim krugovima, preko kojih su širili svoj utjecaj, priskrbili su ulazak u zatvoreno kinesko društvo i s vremenom postizali društveni ugled. Ureman, kao vrstan matematičar i poznavatelje Euklidova djela, poučavao je zapadnjačku matematiku te omogućio prijenos teorijskih matematičkih znanja utemeljenih na aksiomatskom, deduktivnom sustavu u autohtonu kinesku matematiku, koja se je do tada temeljila uglavnom na praktičnim aspektima i postupcima povezanim s rješavanjem problema proizišlih iz zahtjeva praktičnoga života, kao mjerenja zemljišta, određivanja poreza, trgovine, arhitekture, astronomije, određivanja kalendara, proricanja i drugo. ${ }^{31}$ Kineska se je znanost do dolaska isusovaca u 16. stoljeću uglavnom samostalno razvijala, ne imajući bitnije doticaje s razvojem znanosti koji je tekao u drugim civilizacijama, kao indijska i arapska, a osobito bez ikakva kontakta s europskom znanošću. ${ }^{32}$ Uremana je u skladu s njegovim znanstvenim interesima pored matematike zanimala i kineska astronomija (Dadić, 2017, 180), koja se je do 16. stoljeća razvijala na drugačijim znanstvenim temeljima od onih koje je Ureman usvojio u europskoj tradiciji. U tom je razdoblju kineska carska vlast poticala isusovce kao dobre poznavatelje astronomije i matematike da pridonesu astronomiji i poboljšanjima kineskoga kalendara. ${ }^{33}$ Ureman je u skladu sa svojim kompetencijama izučavao kinesku

31 O matematici drevne Kine ne zna se mnogo jer su malobrojni sačuvani pisani dokumenti. Kako su Kinezi imali razrađen kalendar još u 3. tisućljeću pr. Kr., pretpostavlja se da otada sežu početci matematike i astronomije. Kroz stoljeća su nastala mnoga matematička djela. Osobit je procvat doživjela u 13. stoljeću, ali je sve do 16. stoljeća imala praktičan karakter i nije bila deduktivnoga tipa, niti se je temeljila na aksiomima kao europska. Bavili su se praktičnim aspektima i problemima te algoritmima za računanje (za jednadžbe višega stupnja i geometrijske probleme koje su također rješavali algebarski i dr.). Nakon susreta s europskom znanstvenom tradicijom, kineska matematika promijenila je svoj karakter.

32 Razvijali su specifične znanstvene metode proizišle iz njihove autohtone tradicije, a najstariji zapisi sežu u 3. milenij pr. Kr.

33 Kineska astronomija do 16. stoljeća bila je "ekvatorska", usredotočena na opažanje cirkumpolarnih zvijezda. Neki od utjecaja indijske astronomije doprli su do Kine prodorom budizma u 1. stoljeću i u razdoblju od 7. do 10. stoljeća. Prekretnica u kineskoj astronomiji nastupila je u 16. stoljeću, koja se tada obogaćuje novim znanjima zapadne astronomije i kozmologije, novim astronomskim metodama i instrumentima posredovanima preko isusovaca i njihovih misija. Tako je u 17. stoljeću uveden prvi teleskop u Kinu, a 1669. godine obnovljena je Pekinška zvjezdarnica prema nacrtima flamanskoga isusovca Ferdinanda Verbiesta i prema načelima europske astronomije, u kojoj su helijakični izlazi i položaj zviježđa zodijaka temeljili osnovni "ekliptični”" okvir. Isusovci Matteo Ricci i Adam Schal reformirali su kineski kalendar da bi se kalendarski 
astronomiju ne samo kako bi proširio znanja, nego i dao prinos prijenosu znanja iz jedne tradicije u drugu (Dadić, 2017, 180). Pored toga, preveo je na latinski i talijanski jezik dva izvješća portugalskih misionara o njihovu radu i prilikama kršćanske misije u Japanu. Uremanov je prijevod imao važan odraz u europskoj zajednici te je doživio više izdanja na tri jezika. ${ }^{34} \mathrm{Na}$ žalost, prerana smrt prekinula je njegov plodonosan rad i onemogućila da u punini ostvari svoje visoke duhovne i znanstvene potencijale. Preminuo je 22. travnja u Nanchangu u tridesetosmoj godini života, nepunu godinu nakon ulaska u Kinu, iscrpljen bolešću i teškim uvjetima u kojima su živjeli misionari.

\section{Zaključak}

Ivan Ureman bio je dio korpusa učenjaka s početka novovjekovlja koji su izučavanjem i uporabom matematike naznačili početak razdoblja novovjekovne znanosti utemeljene na primjeni matematike i matematičkih metoda u istraživanju prirode. Primjena Euklidove metode u iskušavanju znanstvenih hipoteza i dokaznom postupku, u čemu je Ureman bio vrstan znalac, novovjekovnoj je znanosti omogućila snažan razvitak, veliku akumulaciju novih znanja te njezino odvajanje od filozofije i razvoj novih autonomnih područja.

Srednjovjekovna je znanstvena tradicija razvijala kvalitativan pristup u istraživanju i opisivanju prirode, po uzoru na Aristotela, te je matematiku razmatrala kroz interakciju s filozofijom, gdje se logičkoj strukturi matematike nije pridavalo značenje. Ureman u svojem radu odstupa od te tradicije i u potpunosti je uklopljen u novovjekovni pristup istraživanju. Njegova matematička razmatranja, razvijala su se unutar matematičkoga područja i nisu bila povezana s filozofijom, a matematikom se je, osim unutar njezina autonomnoga područja, koristio i u istraživanju astronomskih pojava, zatim u određivanju zemljopisnih koordinata i istraživanju magnetske deklinacije. Potvrdu o tom nalazimo u njegovoj znanstvenoj korespondenciji, u kojoj opisuje svoja motrenja, matematičku obradu podataka i rezultate provedenih istraživanja. Kompetencijom i djelovanjem Ureman je bio u potpunosti uklopljen u rad znamenitih isusovačkih misija na Dalekom istoku i njihovu ulogu u prijenosu znanja iz europske tradicije u kinesku i obrnuto. Posjedovao je visoku razinu teorijskih i praktičnih znanja i vještina upravo u onim područjima za koja su kineski učenjaci pokazivali osobit interes: matematiku, astronomiju, kalendar i određivanje zemljopisnih koordinata. U području astronomije provodio je opažanja i mjerenja astronomskih pojava i veličina, koje su bile aktualan predmet interesa znanstvene zajednice njegova doba. Ostvario

mjeseci bolje uskladili s astronomskim lunacijama (to je naziv za period izmjene mjesečevih faza koji iznosi nešto više od 29 dana).

34 Taj je Uremanov prijevod izvješća japanskih misionara, načinjen s portugalskoga na latinski i talijanski jezik, objavljen nekoliko puta u Milanu i Napulju, a u skraćenom obliku donosi ga na njemačkom jeziku izdavač poznate misijske edicije Bibliotheca Missionum (Streit, 1929, V, 411-417; usp. Korade, 2003, 263-264). 
je zapažene rezultate pri određivanju pomrčine Mjeseca, magnetske deklinacije i zemljopisne dužine. Radom na određivanju točnoga položaja Macaa dao je vrijedan prinos u vrijeme kada su još bila nepoznata područja Dalekoga istoka. Bio je uklopljen u znanstvena nastojanja svoje epohe, koja su potaknula razvijanje novih astronomskih uređaja, metoda i teorija te omogućila nove dosege. Napustivši Rim, Ureman je tek u manjoj mjeri bio u mogućnosti pratiti velike novosti koje su se učestalo događale u europskoj znanstvenoj zajednici toga doba. Početne impulse za znanstveni rad, koje je dobio u Rimu (1600.-1609.) uspio je u razviti tijekom rada u misijama. Međutim, usprkos znanjima koja je posjedovao, što potvrđuju njegovi domišljati i precizni izračuni, ipak se iz udaljenosti prekooceanskih misija nije mogao aktivnije uključivati i sudjelovati u razvoju svih područja koja su bila od njegova interesa. Iscrpljujuća putovanja, udaljenost od znanstvenih središta i novih spoznaja te konačno i prerana smrt onemogućili su da znanja i potencijali koje je Ureman razvio donesu očekivane plodove. Osobito to vrijedi u području astronomije, u kojoj su nekoliko godina nakon njegova odlaska iz Rima, zaslugom Galilea, Keplera i drugih, načinjena velika astronomska otkrića koja su pokrenula onodobnu znanstvenu zajednicu Europe, u koju se Ureman iz periferije misija nije mogao uključivati koliko je želio, ali joj je ipak aktivno pridonosio te dao vrijedan prinos prijenosu znanja između dviju znanstvenih tradicija.

\section{Literatura}

Bartoli, Daniello (1663). Dell' historia della Compagnia di Gesu. La Cina. Terza parte dell' Asia. Roma: Varese; 2. izd. (1825). Opere, XVII. Bella Cina, Torino: Maretti.

Cordara, Giulio Cesare (1750). Historiae Societatis Jesu, I, Romae:Ex typographia Antonii de Rubeis.

Couplet, Philippe (1686). Catalogus Patrum Societatis Iesu. Pariz: nakladnik nepoznat.

Czvittinger, David (1711). Specimen Hungariae literatae, virorum eruditione clarorum natione Hungarorum, Dalmatarum, Croatarum, Slavorum. Francofurti et Lipsiae: Typis et Sumptibus Jod. Guil. Kohlesii.

Dadić, Žarko (1982). Povijest egzaktnih znanosti u Hrvata: Knjiga I. Zagreb: Sveučilišna naklada Liber.

Dadić, Žarko (1985). Matematički tekst Splićanina Ivana Uremana. Rasprave i građa za povijest znanosti, 4, 1-5.

Dadić, Žarko (2017). Povijest znanosti i prirodne filozofije u Hrvata: (S osobitim obzirom na egzaktne znanosti): Knjiga III.: Rani novi vijek. Zagreb: Izvori.

Euklid (1999). Elementi I-IV. Zagreb: Kruzak

Favaro, Antonio (1866). Carteggio inedito di Ticone Brahe, Giovanni Keplero e di altri celebri astronomi i matematici dei secoli XVI. e XVII. con Giovanni Antonio Magin. Bologna: Nicola Zanichelli.

Grienberger, Christophor (1636). Euclidis sexs primi elementorum libri cum parte undecimi: Ex majoribus Clavii commentariis in commodiorem formam contracti et $P$. Christophorum Grienbergorum e Societate Jesu. Graecii: Ernesti Widmanstadii (prvo izdanje Romae: Apud Haeredes Bartholomaei Zanetti, 1629).

Horvat, Vladimir (2002). Matteo Ricci (1552.-1610.) — apostol Kine: Uz 450 obljetnicu rođenja. Obnovljeni život, 57(4), 481-490. 
Kircher, Athanasii (1654). Magnes sive de arte magnetica opus tripartitum. Romae: Sumptibus Blasij Deversin et Zanobij Masotti Bibliopolarum / Typis Vitalis Mascardi.

Korade, Mijo (1985). Podaci o hrvatskim isusovcima iz XVI. I XVII. stoljeća. Vrela i prinosi, 15, 86-108.

Korade, Mijo (1991). Hrvatski isusovci misionari. Zagreb: Hrvatska pokrajina Družbe Isusove.

Korade, Mijo (2003). Recepcija istraživača i filozofa u 17. i 18. stoljeću koji djeluju u drugim zemljama i kontinentima. Prilozi za istraživanje hrvatske filozofske baštine, 29(1-2), 263-301.

Medina, Juan Ruiz de (1993). Ivan Vreman (Split 1583 - Nanchan 1620): Hrvati među isusovačkim misionarima Japana i Kine. U: Isusovci i hrvatska kultura (str. 200-219). Zagreb: Hrvatski povijesni institut u Beču.

Patrignani, Giusepe Antonio (1730). Menologio di pie memorie d'alcune religiosi della Compagnia di Gesu, II, Venezia: Nicolo Pezzana.

Pfister, Louis (1932). Notices biographiques et bibliographiques sur les Jésuites de l'ancienne mission de Chine: Tome I. Changai: Impremerie de la Mission catholique.

Relatione delle cose piu notabili. Scrite ne gli anni 1691, 1620 et 1621 dalla China. Al molto Rev. In Christo P. Mutio Viteleschi Preposito Generale della Compania di Gesu. (1624), Romae: Bartolomeo Zannetti.

Sommervogel, Carlos (1960). Bibliothèque de la Compagnie de Jésus. V, 258. 360-361, VIII, 242-243. Pariz: Alphonse Picard.

Streit, Robert (1929) Bibliotheca Missionum, V, Aachen: Münster Verlag der Aschendorffschen Buchhandlung.

\section{Arhivsko gradivo}

Biblioteca del Monasterio se San Lorenzo El Real Escorial, Madrid, Španjolska: Ureman, Ioannes, Geometriae speculatiuae compendium. Rkp. Katalog K III a y, 32r-37v. 
Ivan Ureman - Mediator Between Chinese and European Scientific Tradition

On the occasion of the 400th anniversary of his death in the Ignatian Jubilee Year (2021-2022)

\section{Marijana Boric ${ }^{*}$}

\section{Summary}

Ivan Ureman belongs to the corpus of scholars from the beginnings of modern history who, by studying and using mathematics, marked the beginning of modern science by applying mathematics and mathematical methods in the study of nature. The application of Euclid's method for testing scientific hypotheses - in which Ureman was an expert - would enable modern science to develop strongly and separate from philosophy, as well as to develop new autonomous fields. While the medieval scientific tradition developed a qualitative approach in researching and describing nature following the example of Aristotle - and perceived mathematics as interacting with philosophy, in which the logical structure of mathematics was not seen as important, Ureman deviates from this tradition. His mathematical considerations were not connected with philosophy, and he used mathematics not only within its autonomous field but also in the study of astronomical phenomena, as well as in the determination of geographical coordinates and the study of magnetic declination. Confirmation of this can be found in Ureman's scientific correspondence in which he describes his observations, mathematical data processing and the results of his research. Owing to his competence and activity, Ureman was fully integrated into the work of the famous Jesuit missions in the Far East and their role in the transfer of knowledge from the European tradition to the Chinese tradition and vice versa. He possessed a high level of theoretical and practical knowledge and skills precisely in those areas in which Chinese scholars showed a particular interest: mathematics, astronomy, the calendar, and the determination of geographical coordinates. In astronomy he carried out observations and measurements of phenomena which were the current subject of interest of the scientific community of his time. He achieved notable results in studying lunar eclipses, magnetic declination, and geographical longitude. By working to determine the position of Macao, he made a valuable contribution at a time when some areas of the Far East were still unknown. He was rooted in the scientific endeavours of his era, which spurred the development of new astronomical devices, methods and theories, and enabled major astronomical discoveries that impelled the scientific community of Europe of that time, in which Ureman - from the peripheries of the distant East - could not engage as much as he would have liked, but nevertheless in which he was actively involved thus making a valuable contribution to the transfer of knowledge between the two scientific traditions.

Key words: Ivan Ureman; Jesuit missionaries: astronomy; geometry; Euclidean axiomatics; magnetic declination; geographical coordinates; Chinese scientific tradition

* Marijana Borić, Ph.D., Croatian Academy of Sciences and Arts, Institute for the History and Philosophy of Science. Address: Ante Kovačića 5, 10000 Zagreb, Croatia. E-mail:mbuljan@hazu.hr 